\title{
Ovipositing behaviour of Compsobracon mirabilis (Szépligeti) (Hymenoptera, Braconidae) in a cerrado habitat, southeastern Brazil
}

\author{
Jean C. Santos ${ }^{1}$, Leonardo R. Viana ${ }^{1}$, Fernando A. O. Silveira ${ }^{1}$, Angélica M. Penteado-Dias ${ }^{2}$ \\ \& G. Wilson Fernandes ${ }^{1}$
}

\begin{abstract}
${ }^{1}$ Ecologia Evolutiva de Herbívoros Tropicais, Departamento de Biologia Geral, Universidade Federal de Minas Gerais. Caixa Postal 486, 30161-970 Belo Horizonte-MG, Brazil. E-mail: gwilson@icb.ufmg.br

${ }^{2}$ Departamento de Biologia Evolutiva, Universidade Federal de São Carlos. Caixa Postal 676, 13565-905 São Carlos-SP, Brazil.
\end{abstract}

\begin{abstract}
Resumo. Comportamento de oviposição de Compsobracon mirabilis (Szépligeti) (Hymenoptera, Braconidae) em um habitat de cerrado, sudeste do Brasil. O comportamento de oviposição do braconídeo parasitóide, Compsobracon mirabilis (Szépligeti, 1901) é descrito. As observações foram conduzidas em uma região de cerrado localizada em Três Marias, Minas Gerais, Brasil. A oviposição foi feita em um ramo de Alibertia concolor (Cham.) K. Schum.1889 (Rubiaceae), no interior do qual havia treze larvas de uma espécie de Lepidoptera não identificada.

Palavras-Chave. Alibertia concolor; Braconidae; comportamento de oviposição; Hymenoptera; parasitismo.

Abstract. The oviposition behaviour of the braconid parasitoid, Compsobracon mirabilis ( Szépligeti, 1901) is described. Observations were conducted in a cerrado region located in Três Marias, Minas Gerais, Brazil. The oviposition occurred in a branch of Alibertia concolor (Cham.) K. Schum. 1889 (Rubiaceae), inside of which there were thirteen larvae of an unidentified species of Lepidoptera.
\end{abstract}

KeYwords. Alibertia concolor; Braconidae; Hymenoptera; oviposition behaviour; parasitism.

The family Braconidae is represented by parasitoid wasps that attack insects such as Lepidoptera larvae (WHARTON 1993) and some species of plants (MACÊDo \& MonteIro 1989). The influence of braconid wasps in the population dynamics of Lepidoptera larvae has received great attention (see THORPE et al. 1990). Some studies have shown efficient braconid use in biological pest control programs (WHARTON 1993). Due to this influence, more knowledge of their natural history and behavior is an important link in comprehending the multitrophic relationships between parasitoids, their hots and the plants on which the hosts reside. Many of the Compsobracon specimens are particulary large and brigthy colored and have thus been collected quite frequently. Here, we describe the ovipositing behavior of Compsobracon mirabilis (Szépligeti, 1901) on an unidentified species of Lepidoptera larva, inside a branch of Alibertia concolor (Cham.) K. Schum 1889 (Rubiaceae).

\section{MATERIALAND METHODS}

Observations occurred at the Estação Ecológica de Pirapitanga (EEP/IBAMA) in Três Marias, Minas Gerais southeastern Brazil, in December 2002. The EEP is a man-made island, situated in the Três Marias reservoir $\left(18^{\circ} 20^{\prime} \mathrm{S}\right.$ to $18^{\circ}$ $23^{\prime} \mathrm{S}$ and $45^{\circ} 17^{\prime} \mathrm{W}$ to $45^{\circ} 20^{\prime} \mathrm{W}$ ). The altitude varies from 560 to $630 \mathrm{~m}$, annual mean temperature varies from 20 to $22^{\circ} \mathrm{C}$ and annual mean precipitation is $1600 \mathrm{~mm}$. The island is approximately 1100 ha and is composed primarily of cerrado (savanna) vegetation (Gonçalves-Alvim \& Fernandes 2001).

The parasitoid was identified as Compsobracon mirabilis (Szépligeti, 1901) and the voucher specimen is deposited at the Universidade Federal da São Carlos (DCBU), São Paulo, Brazil. The Lepidoptera larva species could not be identified. The host plant for the larvae, Alibertia concolor (Rubiaceae), is a dioecious shrub common in many areas of the eastern and southeastern Brazilian cerrado (PERSSON 2000). We collected the only branch where oviposition was observed. We also observed wood-boring larvae in other individuals of $A$. concolor in the same area.

Field observations were conducted unaided and with the naked eye, following "ad libitum" (sensu Altmann 1974). In total, five individual ovipositing events and related behavior for $C$. mirabilis were observed during a two-hour time span.

\section{RESULTS AND DISCUSSIONS}

Three individuals of $C$. mirabilis were observed flying around the plant. The individuals showed preference to a particular branch by conducting flights more proximate to it following the length of the branch. During one of these events an individual landed on a branch with visible silk (Fig. 1A, 

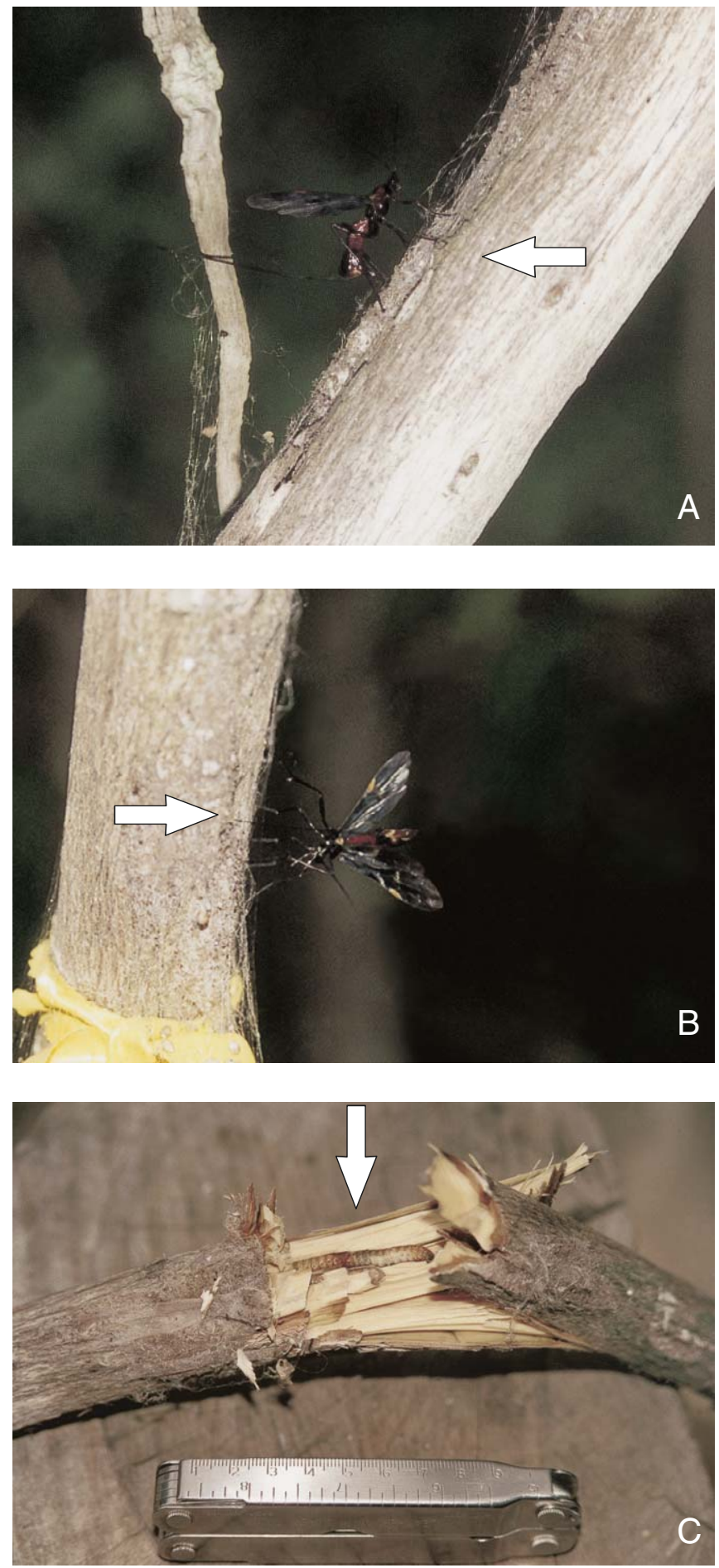

Fig. 1. Behavioral sequence of ovipositing by Compsobracon mirabilis. A) Female with ovipositor almost totally inserted in the branch in the search of caterpillars. The arrow shows a Lepidoptera silken tunnel coverings on the external part of the branch. B) Female inserting the ovipositor into the branch. The arrow shows the exact placement of the insertion. C) Branch of A. Concolor showing caterpillar as was found inside. All pictures by L. R. Viana. arrow) covering larval tunnels, and proceeded walking along it and inserted its ovipositor directly through the wood (Fig. $1 \mathrm{~B}$, arrow); this action was done repeatedly. Once the ovipositor was fully inserted into the branch, the individual displayed wing fanning behavior similar to that observed in braconid courtship and mating studies (MATTHEws 1974). After a short while, approximately ten minutes, it extracted its ovipositor, took flight and continued to fly over the branch.

Thirteen Lepidoptera larvae were found inside the branch. The larvae had bored tunnels into the wood from the location of the silken tunnel covering. From the external surface of the branch the tunnels proceeded into its center then following a path lengthwise along the branch (Fig. 1C). The average diameter of the branch was $2.4 \mathrm{~cm}$, taken from five diameter measurements along its entire length $(n=5)$. The tunnels dug by the larvae had an average width of $0.55 \mathrm{~cm}(\mathrm{n}=5)$, and an average length of $2.50 \mathrm{~cm}(\mathrm{n}=5)$.

Acknowledgments. We thank the Programa de Pós Graduação em Ecologia, Manejo e Conservação da Vida Silvestre/UFMG, FAPEMIG (CRA 388/01) and CNPq (52.1772/95-8 and 479684/2001-4) for support. E.F. Morato for comments on the manuscript, and CNPq for financial support to J.C. Santos. We also would like to thank the Estação Ecológica de Pirapitinga-IBAMA for logistical support.

\section{REFERENCES}

Altmann, J. 1974. Observational study of behavior: sampling methods. Behaviour 49: 227-267

Gonçalves-Alvim, S. J. \& G. W. Fernandes. 2001. Biodiversity of galling insects: historical, community and habitat effects in the neotropical savanna. Biodiversity and Conservation 10: 79-98.

MACÊDo, M. V. \& R. Monteiro. 1989. Seed predation by a braconid wasp, Allorhogas sp. (Hymenoptera). Journal of the New York Entomological Society 97: 358-362.

Matthews, R. W. 1974. Biology of Braconidae. Annual Review of Entomology 19: 15-32.

Persson, C. 2000. Phylogeny of the Neotropical group Alibertia (Rubiaceae), with emphasis on the genus Alibertia, inferred from ITS and 5S ribosomal DNA sequences. American Journal of Botany 87: 1018-1028.

Thorpe, K. W.; M. J. Raupp \& T. M. Odell. 1990. Assessing gypsy moth (Lepidoptera: Lymantriidae) larval mortality caused by the pasasitoid Cotesia melanoscela (Hymenoptera: Braconidae): host age effects. Environmental Entomology 19: 771-775.

Wharton, R. A. 1993. Bionomics of the Braconidae. Annual Review of Entomology 38: 121-143. 